PROBLEMS

OF MANAGEMENT IN THE $21^{\text {st }}$ CENTURY Vol. 15 , No. 1,2020

\title{
A MANAGEMENT TOOL TO AID IN THE TROPICAL OUTBREAK OF THE 21st CENTURY: SENIOR SCIENTISTS AND THEIR KNOWLEDGE OF THE TRIPLE THREAT DENGUE, ZIKA AND CHIKUNGUNYA
}

Jorge Magalhães, Marcos Hir Oswaldo Cruz Foundation/FIOCRUZ - Institute of Drugs Technology/Farmanguinhos, Brazil E-mail: jorge.magalhaes@far.fiocruz.br, marcos.hir@far.fiocruz.br

Luc Quoniam

University of Toulon, France Federal University of Mato Grosso do Sul, Brazil

E-mail: mail@quoniam.info

Zulmira Hartz

NOVA University Lisbon, Portugal E-mail: zhartz@ihmt.unl.pt

Daniele Alves de Oliveira Oswaldo Cruz Foundation/FIOCRUZ - Biomanguinhos, Brazil E-mail: daniele@bio.fiocruz.br

\begin{abstract}
The 21st century presents itself as the informational and knowledge age. The aging population and the technological innovation to medicine have been a constant concern due to the search for the complete state of well-being of the individual. Nations are making increasing efforts to continually improve their populations. There is an urgent need for better management of knowledge and integrality of health care, such as the integration, convergence and pragmatism of actions in multiple areas. According to the World Bank and the World Health Organization, half the world's population does not have access to essential health services and more than 1 billion are threatened by neglected diseases. Therefore, information science aid in the complexity of identifying, extracting, and treating the quintillions of data added daily to the Web. After processing by ScripLattes tool thousands of resumes on the Lattes platform, 39,046 triple threat experts have been identified, but only $0.3 \%$ are senior competencies. The scientific papers published in Dengue fever, Zika virus and Chikungunya fever are 11,743. The ScripLattes tool proved to be efficient to support in the management of scientific knowledge in public health. Thus, this research provides an overview from the core competencies in triple threat in Brazilian territory and their mainly scientific and technological publications.
\end{abstract}

Keywords: knowledge management, information science, public health, triple threat. 
Jorge MAGALHÃES, Marcos HIR, Luc QUONIAM, Zulmira HARTZ, Daniele Alves de OLIVEIRA. A management tool to aid in the tropical outbreak of the 21st century: Senior scientists and their knowledge of the triple threat dengue, zika and chikungunya

\section{Introduction}

The 21 st century has been regarded as the information age, the era of integrative knowledge across all areas of science. Information science has been a strong ally in providing the mastery of the various information technologies, through continuing education in this competitive global market in constant change (Floridi, 2010; Quoniam, 2011). Thus, information be a condition for survival, given that it expands the context of communication by rescuing and preserving social memory. Its value is intangible and resists all mechanisms of oblivion and destruction since the collection of informative reconstruction allows the cognitive and knowledge assessment of a given reality in question. Therefore, information technologies must be considered basic work tools, since their technical processing, management, retrieval and dissemination of information, through technologies, are increasingly efficient and effective (Dehmer \& Emmert-Streib, 2017; Magalhaes \& Quoniam, 2015; WIPO, 2019).

The new millennium has brought great challenges for the management of information and knowledge in all areas of science. Regarding the Big Data phenomenon, about 2,5 x $10^{\wedge} 18$ bytes de data since the year 2012. Between 2013 and 2020, it is estimated that the volume of global data will grow exponentially, from 4.4 zettabytes to 44 zettabytes. By 2025 , data generation is expected to reach 163 zettabytes (IDC, 2012; Reinsel et al., 2018).

In this concept, health is no different. It is necessary a broad management that feeds back with a constant evaluation for continuous improvement and that provides the well-being to the society and that still adds value. The generation and delivery of this value to society depends on the development of a management model based on sustainable and innovative practices without losing the technological evolution provided by the constant changes in paradigms. In line with this idea, one must bear in mind the relevant role of organizations to think about health in its broad sense of the Economic and Industrial Health Complex (CEIS - Brazilian term) (Gadelha et al., 2012; Lima de Magalhães et al., 2013). In this regard, one must combine the challenges and opportunities that the 21 st century presents - the fourth technological revolution - the exponential era of information marked by large-scale connectivity, Big Data processing, the internet of things, that is, resulting technologies of a strong global innovation movement.

Whereas information science is the science and practice that deals with the effective collection, storage, retrieval and use of information; it facilitates the management of the knowledge absorbed for its use (Dehmer \& Emmert-Streib, 2017). Therefore, the management of this knowledge obtained by the convergence of data transformed into information, requires the involvement and support of all stakeholders of the company or research institutes, in order to preserve, transmit and develop knowledge. In fact, it is the individuals who are at the center of creating value and have the keys to the success of such a project. The management of an organization's knowledge and know-how is not universal but depends heavily on the culture of the country in which it is carried out (Balmisse, 2006).

Knowledge Management requires the involvement and support of all the company's stakeholders to preserve, transmit and develop knowledge. Indeed, it is the individuals who are at the center of the creation of value and who hold the keys to the success of such a project. The management of the knowledge and know-how of the company is therefore not universal, it depends strongly on the culture of the country in which it is practiced (Balmisse, 2006a).

Knowledge management is a field under the management science theory, although the notion links an epistemological concept (knowledge), a concept that is at the center of many philosophical debates and that is linked to the perspective of efficient action in the company. The hybridization which results from the simultaneous use of the two terms induces the idea of an action situated in relation to teleological knowledge or, in other words, beliefs and certainties of a very particular nature. This hybridization is also described as one of the signs of the institutionalization of the company which is today supposed to create and manage knowledge (Cowan, 2001; Pirró et al, 2010).

In order to manage some knowledge, it is first necessary to have information and, therefore, to have data to be processed (Antunes, et al., 2013; Jamil et al., 2013; Lawrence $\mid \begin{aligned} & \text { PROBLEMS } \\ & \text { OF MANAGEMENT } \\ & \text { IN THE 21 } 1^{\text {st }} \text { CENTURY } \\ & \text { Vol. 15, No. 1, } 2020\end{aligned}$ 
Jorge MAGALHÃES, Marcos HIR, Luc QUONIAM, Zulmira HARTZ, Daniele Alves de OLIVEIRA. A management tool to aid in the tropical outbreak of the 21st century: Senior scientists and their knowledge of the triple threat dengue, zika and chikungunya

OF MANAGEMENT IN THE $21^{\text {st }}$ CENTURY Vol. 15, No. 1, 2020

42

\& Giles 2000b). According to (Balmisse, 2006b), the different notions to the definitions of Knowledge are: Knowledge is the information assimilated to carry out an action; Information is the data put into context; and, Data are the gross element outside of context.

The management of knowledge is presented as a major stake in the functioning of organizations and societies. It is also under this common denominator that the link between the knowledge-based enterprise and the knowledge-based society is established, the development of knowledge-based enterprises being in the direction of building a Society of knowledge just like yesterday in the conservative vulgate, the prosperity of the enterprises was assuring that of the companies, and the global employment as the sum of the jobs of the enterprises. This makes it possible to assert that the understanding of the enterprise of knowledge is the only valid one, without really having to face the problem of the transition from the enterprise to the knowledge society (Pesqueux, 2005a).

Therefore, a management analysis is necessary to integrate actions and to provide the effectiveness actions to generate technological innovation and consequently wealth of the country. Thus, a better management for information architecture, also known as business architecture, encourage a new understanding (Ross et al., 2006).

In this sense, to motivate individuals to share their knowledge, cultural and human factors must be considered, rather than just tools and procedures. "Culture" as the set of values, norms, habits and specific customs of a society influences the individual's personality and contributes to reflection and advancement of knowledge in all its aspects, such as scientific and technological (Magalhaes et al., 2018; Pesqueux, 2005b; Pesqueux \& Ferrary, 2011).

According to Morin (1982), it is necessary to raise the concept of "system" from this theoretical level to the paradigmatic level that commands / controls all the knowledge existing in all discourses and theories. Thus, to sustain the cycle of action (application) of knowledge to the progress of action, it is necessary to try to identify / define what these notions are, presenting the new paradigm and returning as the (re) definition of the system where the logic of complexity in modeling of real performance interacts with the posture of the researcher and the actors involved in the evaluation process (Hartz, 2013; Morin, 1982; Piaget \& Garcia, 1983).

In this sense, identifying, classifying, measuring, disseminating and training competencies are essential to help strengthen Research, Development and Innovation (R, D\&I) in Health Science, Technology and Innovation Management. According to Hartz (1997), evaluation and health are characterized by phases. The first is "systematize" and refers to a "structuralist and cybernetic" practice supported by mathematical theories that support the analysis of hard systems (Hartz, 1997; Le Moigne, 1994).

Therefore, it is not trivial to treat about 10 quintillion daily data added to the Web, where about $50 \%$ are related to health and $47 \%$ to public health. Constant monitoring of science, technology and the market is urgent in order to contribute to the advancement of new treatments for diseases that affect both developed and developing countries (Magalhaes et al., 2015).

Specifically, Brazilian scientific knowledge is listed in the repository of the National Council for Scientific and Technological Development (CNPq) - the Lattes database. It is a curricular repository that gathers qualified and updated information on the performance of researchers in Science, Technology and Innovation. The information is registered by professors, students and researchers in the country. It is a sine qua non condition to be registered and with updated curriculum to obtain funding, scholarships and participate in the teaching staff in the country. Lattes curricula are considered a national standard of assessment, representing a history of scientific, academic and professional activities of researchers registered on the platform (Jesús Pascual Mena-Chalco \& Cesar Junior, 2009; Mena-Chalco et al., 2013).

The lattes platform (lattes.cnpq.br) contains informational and available data from almost 4 million scientific and technological curricula. Although this data is available for consultation, compiling or summarizing bibliographic productions for a group of users registered on the platform requires a great deal of manual effort and is susceptible to failure. For this reason, mapping all the scientific, technological productions and respective collaborations generated 
Jorge MAGALHÃES, Marcos HIR, Luc QUONIAM, Zulmira HARTZ, Daniele Alves de OLIVEIRA. A management tool to aid in the tropical outbreak of the 21st century: Senior scientists and their knowledge of the triple threat dengue, zika and chikungunya

from a specific interest group, becomes an arduous job to be done - manually and subject to failures. In this sense, the data mining scriptLattes automatically provides the extraction and processing of Lattes curricula for the group in question. Once the operation is carried out, the requested management information is presented with "data visualization" for the management decision making. It is viewed in an HTML page (Brito et al., 2016; Mena-Chalco et al., 2013). This method of data analysis can be replicated for any area of science (Magalhaes et al., 2014).

Therefore, to assist in the management of health data, it was chosen as a study of this manuscript, to contribute in the area of Neglected Diseases (ND). According to Moon et al, 2012, this area of public health is relevant, as it was found that the current system of Research, Development and Innovation (R, D \& I) of new drugs does not adequately meet the needs of who live in low and middle income countries. This population already accounts for more than $80 \%$ of the world population. This reality is enhanced with the possibility of the emergence of endemic diseases that perpetuate the conditions of poverty (Moon et al., 2012).

According to the World Bank and the World Health Organization (WHO) half of the population does not have access to essential health services (WHO, 2018; World Bank, 2018). The WHO also lists 17 diseases that are on the list of ND, but this list always gets added as researchers identify new problems that need to be addressed. In 2010, according to data published by the WHO, it is estimated that there are about 1 billion people in the world suffering from some ND. Although these diseases primarily affect populations in developing countries, they have increased in developed countries and have a devastating impact on humanity. Annually, ND cause between 500 thousand and 1 million deaths (Valverde et al., 2015; WHO, 2010).

Among the ND, three diseases transmitted by the Aedes aegypti mosquito stand out, and together they constitute the triple threat, they are dengue, zika fever and chikungunya. Dengue is a viral infection that causes a serious flu-like illness; the incidence of dengue has increased 30 times in the last 50 years, and it is estimated that 50 to 100 million infections occur annually in more than 100 endemic countries. Zika, on the other hand, is an acute viral disease, which has a benign evolution in most cases, but there has been the occurrence of deaths from the disease, an increase in cases of microcephaly and neurological manifestations associated with the disease. Finally, chikungunya is a viral disease that in recent years has proliferated in the region of the Americas, specifically reaching Brazil. Infection caused by the disease is rarely fatal, but it causes fever and severe joint pain in most people (Magalhaes et al., 2018). The similarities between the symptoms of the three diseases can be seen in Figure 1.

\section{Figure 1}

Intersection relationship of symptoms between dengue, zika and chikungunya

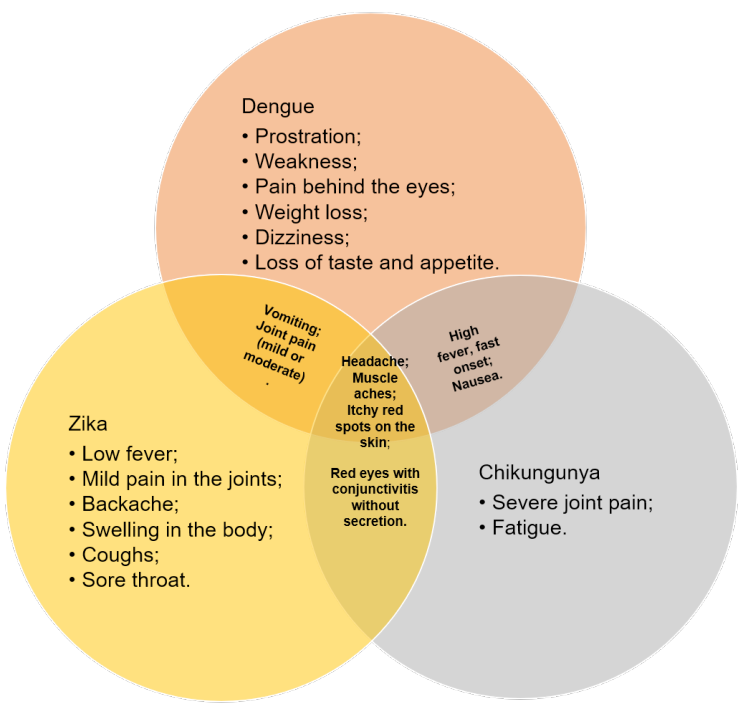

Source: (Magalhaes et al., 2018).

\author{
PROBLEMS \\ OF MANAGEMENT \\ IN THE $21^{\text {st }}$ CENTURY \\ 43
}


Jorge MAGALHÃES, Marcos HIR, Luc QUONIAM, Zulmira HARTZ, Daniele Alves de OLIVEIRA. A management tool to aid in the tropical outbreak of the 21st century: Senior scientists and their knowledge of the triple threat dengue, zika and chikungunya

OF MANAGEMENT IN THE $21^{\text {st }}$ CENTURY Vol. 15 , No. 1,2020

The biggest problems and challenges in the control of these diseases are the lack of vaccines (in the case of zika and chikungunya), the extensive areas of spread of the mosquito, insufficient scientific knowledge to reduce the populations of the vector, problems in the detection and early notification of the cases of the disease and the fragility of the integration between entomological surveillance and epidemiological surveillance (Bales et al., 2011). In addition, the three highest dengue rates in the country and the emergence of chikungunya and zika occurred in this decade, as identified in the graph in Figure 2 through the study of Sense Company (https://www.wearesense.company/) para a Oxitec (https://www.oxitec.com/ ) (Ministério da Saúde, 2018).

\section{Figure 2}

Notified cases of dengue, chikungunya and zika in Brazil per year

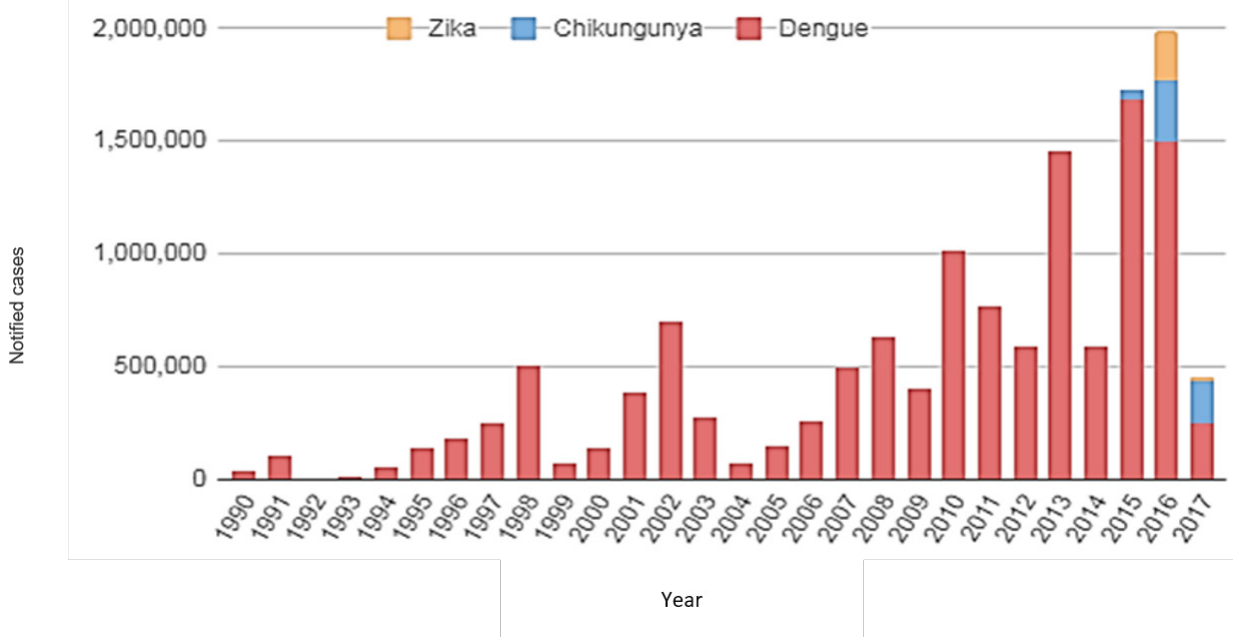

Source: (Flores \& Silveira, 2011, 2011; Ministério da Saúde, 2018).

In view of this scenario and the technological evolution in the face of Big Data in health, it is necessary to think about better planning for investments in R, D \& I in order to combat the problems that affect humanity (J. L. de Magalhães et al., 2018). In this sense, the present work deals with the relevance of the Brazilian platform Lattes, as well as of the extraction and treatment of the existing scientific data in it, in order to identify the essential senior competences and respective correlations with national and international scientists. This is justified, in that the success in the identification and mapping, contributes as an important management tool for the decision makers of the organizations and, in this way, a contribution in the public health scenario to face the triple threat of tropical dengue, zika and chikungunya.

Therefore, it is necessary to use information science to gather and use its theories, principles, techniques, and technologies from a variety of disciplines to solve knowledge management problems. In this case, the use of the ScriptLattes tool is to assist a part of public health management.

Therefore, the main objective of the research was to identify the main senior scientists in Brazil and their core scientific and technological productions in the area for the triple threat in public health. 
Jorge MAGALHÃES, Marcos HIR, Luc QUONIAM, Zulmira HARTZ, Daniele Alves de OLIVEIRA. A management tool to aid in the tropical outbreak of the 21st century: Senior scientists and their knowledge of the triple threat dengue, zika and chikungunya

\section{Research Methodology}

General Background

This research was carried out based on scientometry and bibliometry of open data in science. In this way, an open-source knowledge extraction system from the Brazilian Lattes platform (ScriptLattes) was used. In this Platform, all senior scientists, and their respective scientific and technological productions most relevant to dengue, zika and Chikungunya were identified. ScriptLattes is a free and open source GNU-GPL script. It is possible to perform automatic data extraction and compilation, generating metrics, collaboration graph and geolocation map. The program was run in a Linux environment. The data, after being identified and processed generating management information, were grouped, organized, and made available in an HTML environment on the Web.

The search was limited to obtain the greatest senior specialists in the country, specifically with terms in English and Portuguese, such as: "dengue", "zica", "zika", "chicungunha" and "Chikungunya", as well as the terms "denv", "zikv" and "chikv". Boolean expressions (see figure 3) "AND", "OR", "NOT" and "NEAR" were used. For example: dengue OR zika OR zica OR chikungunya OR chicungunha OR denv OR zikv OR chikv. Searches used terms in parentheses and quotation marks in order to combine these operators for a more complete search. The filtering options and criteria in this field were also used, such as obtaining the level and nationality of the registered curriculum, as well as having "CNPq Productivity Scholarship", "Presence in the Research Group Directory".

\section{Figure 3}

Lattes Platform screen for advanced searches.

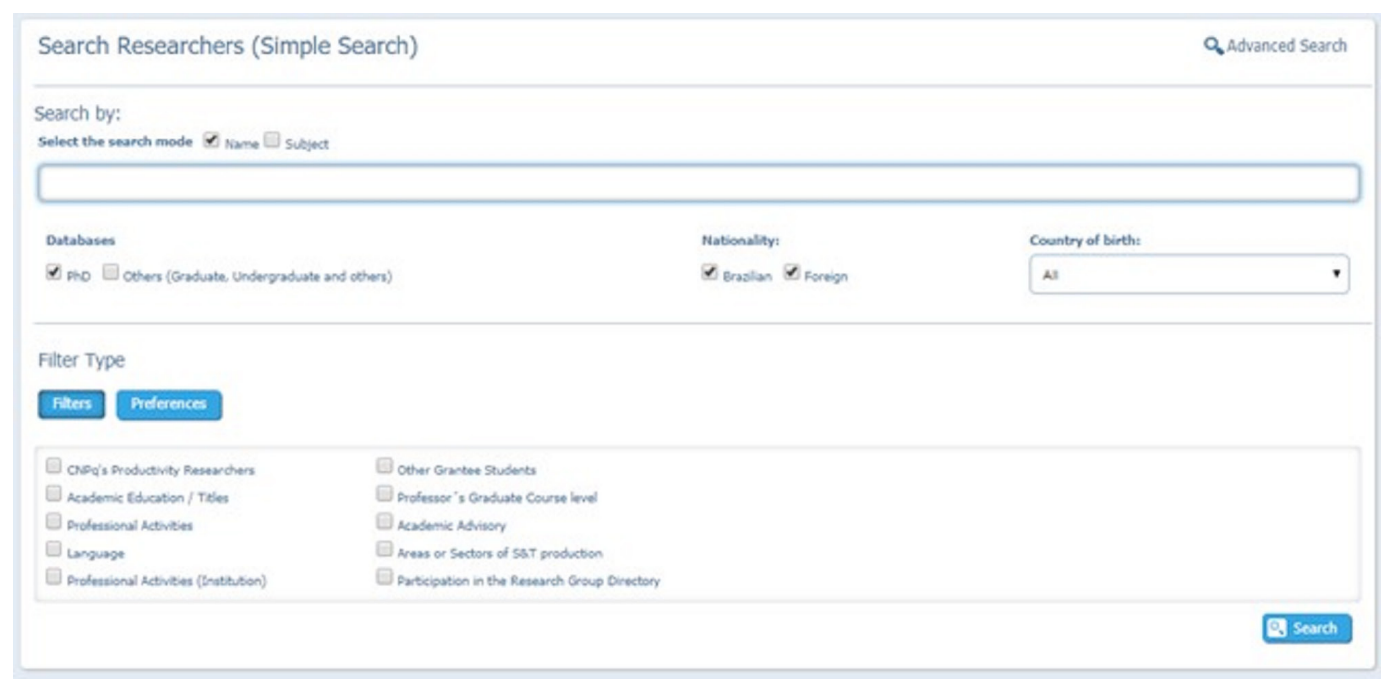

Source: CNPq (2020).

In order to obtain the Brazilian public health, epidemiological scenario and guidance on knowledge and information management, searches in scientific journals available in indexed databases, such as Scielo, PubMed and Scopus, were used. Likewise accessed official databases, such as the Ministry of Health (http://portalms.saude.gov.br/ e OMS (https://www.who.int/). 
Jorge MAGALHÃES, Marcos HIR, Luc QUONIAM, Zulmira HARTZ, Daniele Alves de OLIVEIRA. A management tool to aid in the tropical outbreak of the 21st century: Senior scientists and their knowledge of the triple threat dengue, zika and chikungunya

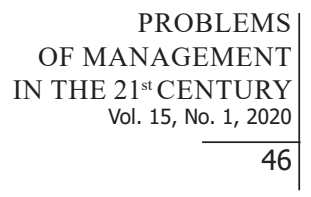

OF MANAGEMENT $21^{\text {st }}$ CENTURY

46

\section{Data Analysis}

It is worth highlighting that management of data analysis is done using an inductive research approach and collected. Based on a large sample of qualitative data, cost-and-benefit analysis is used to assess several technologies as a strategic (Miles \& Huberman, 1994). Data analysis is a process of inspecting, cleansing, transforming and modeling data with the goal of discovering useful information, informing conclusions and supporting decision-making. In this context, there is data mining like a particular data analysis technique that focuses on statistical modeling and knowledge discovery for predictive rather than purely descriptive purposes, while business intelligence covers data analysis that relies heavily on aggregation, focusing mainly on business information (Miles \& Huberman, 1994; Selene Xia \& Gong, 2014). In this sense, qualitative Data Analysis remains the most comprehensive and complete treatment of this topic currently available to scholars and applied researchers.

Thus, data analysis has multiple facets and approaches, encompassing diverse techniques under a variety of names, and is used in different business, science, and social science domains. In today's business world, data analysis plays a role in making decisions more scientific and helping businesses operate more effectively (Minelli, et al., 2013).

\section{Research Results}

Thus, considering that the data available in health are configured as a Big Data problem and that the manipulation of them is not solved by trivial models, as they are presented with an enormous volume of structured and unstructured data generated every second; it becomes difficult to process them using traditional means of databases, software and techniques. However, there is a need to use specific tools, such as data mining programs (Arasu \& GarciaMolina, 2003; Magalhães et al., 2018).

By defining the search strategy in the existing curricula on the Lattes platform, a series of tests was carried out with terms "dengue", "zica" "chicungunha". This preliminary research took place in order to visualize the number of researchers related to the triple threat in relation to all the options that the lattes platform provides. For that, the "advanced search" field (Brazilian term) was considered for 07 (seven) items of variables, as shown in Table 1. The search strategy was: ((dengue) AND (zika OR zica) AND (chikungunya OR chicungunha)) OR (triple threat). The results indicated from 2943 resumes for the first item (variable) of the search, up to 105 resumes for the last item (variable). Given the question of identifying the core competencies for triple threat in Brazil, the choice (variable) number 7 (seven) was chosen as the strategy for identifying and extracting curricula on the basis of lattes, namely: "Brazilian doctors with any level of productivity scholarship and presence in the Research Groups directory "(Brazilian term - Brazilian doctors with any level of productivity grant and presence in the GP directory) - see Table 1. 
Jorge MAGALHÃES, Marcos HIR, Luc QUONIAM, Zulmira HARTZ, Daniele Alves de OLIVEIRA. A management tool to aid in the tropical outbreak of the 21st century: Senior scientists and their knowledge of the triple threat dengue, zika and chikungunya

\title{
Table 1
}

Number of researchers identified in the Lattes database containing the search terms listed in the method

\author{
PROBLEMS \\ OF MANAGEMENT \\ IN THE $21^{\text {st }}$ CENTURY \\ Vol. 15, No. 1, 2020 \\ 47
}

\begin{tabular}{lll}
\hline Item & Criteria selected for searching in the Lattes database & $\begin{array}{l}\text { Number of resumes identified } \\
\text { Lattes }\end{array}$ \\
\hline 1 & All (doctors and other researchers, Brazilian and foreign) & 2943 \\
\hline $\mathbf{2}$ & Brazilian and foreign doctors & 1024 \\
\hline $\mathbf{3}$ & Brazilian doctors & 997 \\
\hline $\mathbf{4}$ & Brazilian and foreign doctors with any level of productivity scholarship & 119 \\
\hline $\mathbf{5}$ & Brazilian doctors with any level of productivity scholarship & 112 \\
\hline $\mathbf{6}$ & $\begin{array}{l}\text { Brazilian and foreign doctors with any level of productivity grant and } \\
\text { presence in the GP directory }\end{array}$ & 110 \\
\hline $\mathbf{3}$ & $\begin{array}{l}\text { Brazilian doctors with any level of productivity grant and presence in the } \\
\text { RG (research group) directory }\end{array}$ & 105 \\
\hline
\end{tabular}

Source: created by the authors based on data platform Lattes, 2020.

It should be noted that the Lattes database provides other filters for consultation. Therefore, they were applied, but the results showed inconsistency in the lattes base. The reason for the inconsistency may be linked to several factors, such as, for example, the researchers' failure to fill in the data or even the error of the Latte Platform itself1.

Among the other filters applied in the retrieval of data, we exemplify "Level of the Postgraduate Course where you are a Teacher" - the system returned with a negative result. In the same way when trying to restrict the search to updated curricula at any time other than the last 48 months, the result returned just like the search was first performed (the values remained the same as any first search performed).

In view of the limitation, it was decided to redeem only the 105 resumes obtained in the search for item 7 in Table 1. This cut allowed obtaining specialist doctors, both Brazilian and foreign, who have a productivity scholarship at any level and still belong to a group of professionals. Therefore, with this "cut" it was possible to retrieve the 105 Lattes Identification (ID) numbers of the curricula. Subsequently, a list was created with the 105 ID (registration numbers in the researcher in the lattes base) that would be used in the ScriptLattes program.

Using Linux-based processing, the researchers' IDs (ID list) were inserted and the ScriptLattes treatment was performed (see http://scriptlattes.sourceforge.net/ ). The data identified and extracted from the 105 researchers, generated scientific and technological information, with the best skills in the area in question (dengue, zika and chikungunya). Detailed results, in full, are available at the following email address http://vlab4u.info/Triplice-Ameaca/.

Briefly, there are some highlights: the main page, in HTML, can be seen in Figure 4. The header shows the links where members can be seen (senior competences in the triple threat), the bibliographic production of these specialists, technical production etc. Special emphasis on the graph of collaborations that these specialists have among themselves - the more interactions between them, the greater the clusters formed. The correlation metrics between them were also obtained. In the item "bibliographic production" and "technical production", several sub-items 1 On 08/15/2019, an email was sent to the address atendimento@cnpq.brinforming of the inconsistency found during the consultation and data extraction in the Lattes database and requesting assistance on the matter. However, until the end of the present work, the authors did not get a response. 
Jorge MAGALHÃES, Marcos HIR, Luc QUONIAM, Zulmira HARTZ, Daniele Alves de OLIVEIRA. A management tool to aid in the tropical outbreak of the 21st century: Senior scientists and their knowledge of the triple threat dengue, zika and chikungunya

OF MANAGEMENT IN THE $21^{\text {st }}$ CENTURY Vol. 15 , No. 1,2020

are presented, where for each one, the amount of recovered works is in parentheses, as a senior repository of senior specialists in the triple threat. For example, 11743 articles on dengue, zika and / or chikungunya were found in only full articles published in journals. The sum of all "Bibliographic Production" corresponds to a total of 47,894.

\section{Figure 4}

\section{Main menu generated by scriptLattes}

Mapping of Scientific and Technological Skills in Dengue, Zika and Chikunguya

[ Members | Bibliographic Production | Tecnical Production | Artistic production | Artistic production | Projects | Awards | Events | Collaboration Graph | Geolocation Map | Metrics ]

\section{Bibliographic Production}

- Complete articles published in journals (11743)

Published/organized books or editions (153)

- Capítulos de livros publicados (938)

- Chapters of published books (442)

- NewsPaper/NewsPaper texts (1032

- Full papers published in congress proceedings (313)

- Abstracts published in conference proceedings (10016)

- Articles accepted for publication (73)

- Work Presentations (3496)

- Orther types of bibligraphic production (241)

- Total bibliographic production (28447)

Technical production

- Technological Products (104)

Source: Capture of the own elaboration screen (translated into English) ScriptLattes: (Mena-Chalco \& Cesar Junior, 2009)

It is worth mentioning that the information referring to the year 2019 was considered until the script was executed, on September 16, 2019. Therefore, data inserted in the Lattes Platform by the specialists after this date, were not computed in the present research. Another observation is that the curriculum of these specialists includes "expertise" in addition to diseases related to the triple threat. However, considering the method used, it can be attested that the 105 specialists identified are the seniors in the area in question, as they have been active in the last 48 months, have active Research Groups and have an active productivity grant. As an example, in figure 5, some of the results are observed, such as technical productions, research projects, awards and ongoing guidelines.

By clicking on any menu item, you can view the evolution of the 11,743 scientific or technological productions (Figure 5), types of guidelines completed, etc. You can also access the production and download it. 
Jorge MAGALHÃES, Marcos HIR, Luc QUONIAM, Zulmira HARTZ, Daniele Alves de OLIVEIRA. A management tool to aid in the tropical outbreak of the 21st century: Senior scientists and their knowledge of the triple threat dengue, zika and chikungunya

\section{Figure 5}

Examples of results that can be viewed from the index listed in the figure 4

$\mid \begin{aligned} & \text { PROBLEMS } \\ & \text { OF MANAGEMENT } \\ & \text { IN THE 21 } 1^{\text {st }} \text { CENTURY } \\ & \text { Vol. 15, No. 1, } 2020\end{aligned}$

Mapping of Scientific and Technological Competencies in Dengue, Zika and Chikunguya

Artigos completos publicados em periódicos

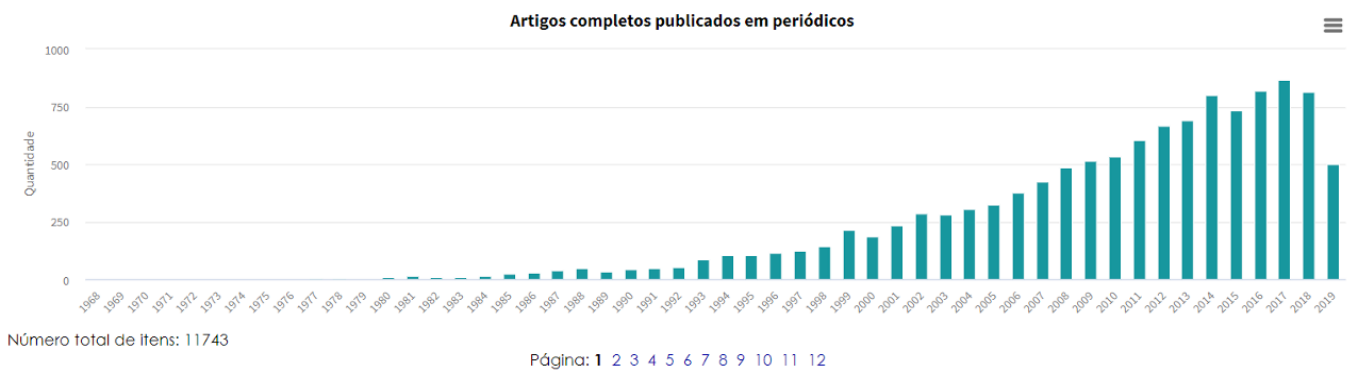

2019

1. A. DUARTE, MATHEUS; F. SILVA, JOÃO M. ; R. BRITO, CLARA ; S. TEIXEIRA, DANILO; L. MELO, FERNANDO ; M. RIBEIRO, BERGMANN ; NAGATA, TatsuYa ; S. CAMPOS, FABRíCIO. Faecal Virome Analysis of Wild Animals from Brazil. Viruses-Basel. v. 11, p. 803, issn: 1999-4915, 2019. ado

Source: extracted by the authors through the scriptLattes tool.

Other points that deserve to be highlighted are the geolocation map shown in figure 6 , the graph of collaborations and the metrics of each Lattes curriculum. In geolocation, the point on the map of the performance of each researcher is observed in line with the professional address that each specialist informed in his resume. By clicking on the symbol "', it is possible to see the name of the senior specialist in the triple threat, the Institute in which it is located and its link to the Lattes curriculum.

\section{Figure 6}

Location map of essential skills in dengue, zika and chikungunya

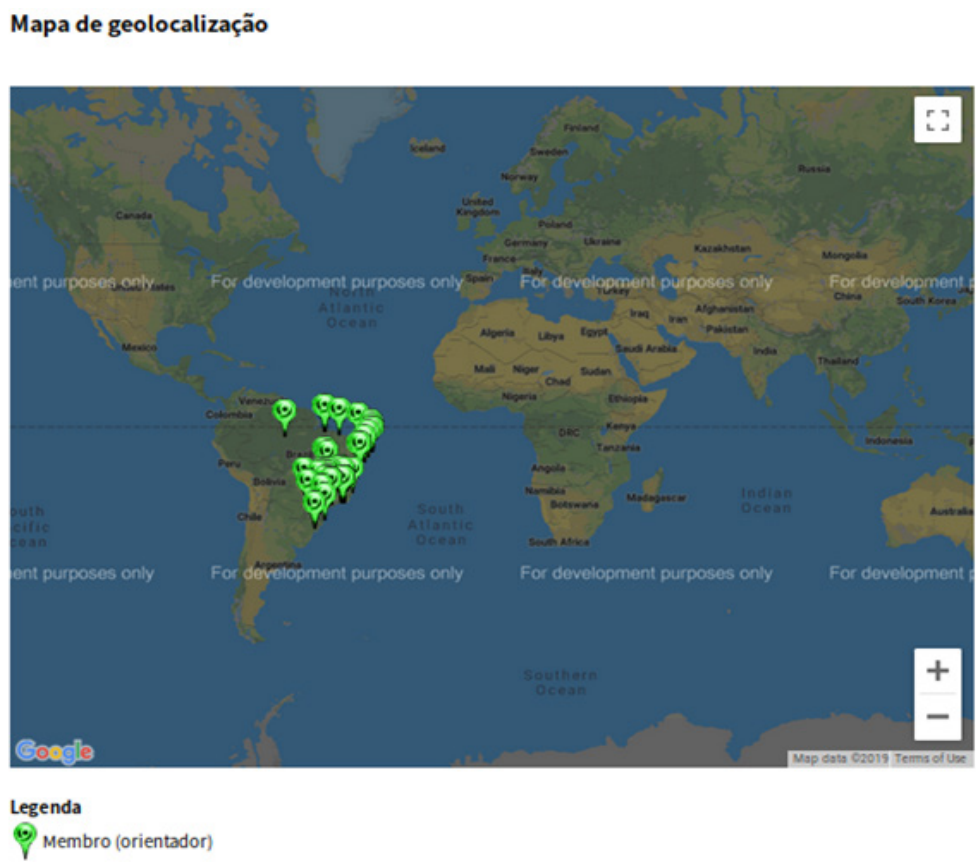

Source: extracted by the authors through the scriptLattes tool. 
Jorge MAGALHÃES, Marcos HIR, Luc QUONIAM, Zulmira HARTZ, Daniele Alves de OLIVEIRA. A management tool to aid in the tropical outbreak of the 21st century: Senior scientists and their knowledge of the triple threat dengue, zika and chikungunya

PROBLEMS

OF MANAGEMENT IN THE $21^{\text {st }}$ CENTURY Vol. 15, No. 1, 2020
The network of collaborations between the senior scientists, could be obtained by "crossing" the data. A "snip" of the intersection and identification of the greater or lesser number of collaborations can be seen in Figure 7.

\section{Figure 7}

Graph of collaborations of essential skills in dengue, zika and chikungunya

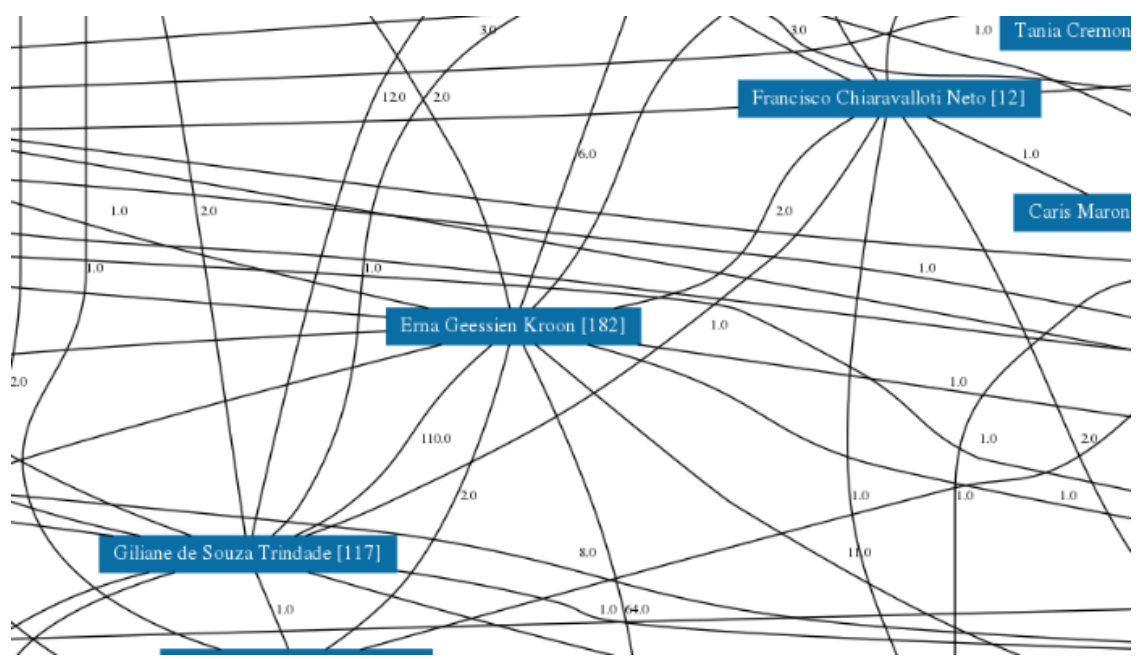

Source: extracted by the authors through the scriptLattes tool

To view all results, better accuracy of essential information and recovery of senior skills in Brazilian territory for the triple threat of dengue, zica and chicungunha, access http://vlab4u. info/Triplice-Ameaca/.

\section{Discussion}

In the age of knowledge, intellectual capital has played an important role in the economy and business. A key component for competitiveness and, therefore, for economic and technological development. In areas of high density, such as pharmaceutical, aerospace and telecommunications, among others of equal weight and impact, knowledge becomes the most important asset (Lastres, HMM \& Sarita, 1999).

Thus, thinking about data integration to use the processed information, helps to solve contemporary problems and challenges. In the field of health, it is necessary to understand it with Gadelha (2012) classified it: by its social dimension and as a source of wealth, configuring a CEIS that links high dynamic industrial segments and the provision of assistance services. This complex incorporates the new technological paradigms that determine the dynamism and long-term competitiveness of national economies, such as fine chemistry, biotechnology, microelectronics and new materials, nanotechnology, the sustainable use of biodiversity, among others. Virtually all segments included in the third technological revolution, fundamental to the Brazil of the future, have a critical space in their development in health (Costa et al., 2012).

The volume and variety of data found on the Brazilian scientific platform Lattes constitutes a "Big Data" of senior scientific and technological productions. The identification, data extraction, classification and making available to society of this essential information, constitute a true world heritage for the reflection of the advancement of science and technology.

It is important to highlight that the Brazilian scientific platform Lattes has 3,520,867 registered resumes. Of this total, 132,631 doctors, that is, only $0.0004 \%$ of the total curricula are specialist doctors (BRASIL, MCTI., 2016). 
Jorge MAGALHÃES, Marcos HIR, Luc QUONIAM, Zulmira HARTZ, Daniele Alves de OLIVEIRA. A management tool to aid in the tropical outbreak of the 21st century: Senior scientists and their knowledge of the triple threat dengue, zika and chikungunya

The main page of the mapping performed, seen in figure 3, presented the general index of the report processed by scriptLattes. In other words, there are links to the results of the information generated after extraction and processing of each data available in the Lattes curricula considered in the research. Obtaining and processing manually would be extremely difficult when big data for large groups like the one surveyed. Therefore, it is configured as a tool to support managers and decision makers in strategic planning, in the performance of research institutions and to anticipate changes in the scope of public health. Regarding the knowledge of productions, guidelines, research projects, awards and events, they are presented in the form of graphics.

Another important option of the available mapping is to visualize the geolocation of the senior scientists. On the main page on the link "graph of collaborations", it is possible to view the ranking of collaboration of one member (senior scientist) with another of the total network of 105 senior specialists. This ranking is like the "pager rank" for directional graphs. As for the link on the main page for "metrics", you can obtain a table containing all the data that were identified and retrieved in each curriculum of the Lattes database.

Regarding the network of collaborations of scientific or technological research by senior scientists, it can be verified in the Collaborations Graph. It shows all 105 researchers. It is noted that among them, it is possible to identify the greatest collaborators in relation to the triple threat; highlighting the scientist "Erna Gessien Kroon" - reached the largest number of collaborations on the network (Figure 7).

\section{Conclusions}

The 21st century has brought new challenges for knowledge management and technological innovation. This fact presents numerous opportunities such as network research, open data, collaborative intelligence and the comprehensiveness of Big Data. In the field of science and technological development in health it is no different. Thus, the development of new methodologies for data identification, extraction and processing is imminent to obtain essential information and assist managers and decision makers.

The importance of Big Data correlations linked to Health, combined with collaborative tools are fundamental in the 21 st century to search for and identify essential information. This fact occurs, precisely in the fact that in the globalized world everything is constantly changing. Therefore, seeking and investing in knowledge management for technological innovation is essential. About public health, this search becomes even more essential, in order to provide decision makers in the field of public health with reliable and essential information.

In the country, 105 senior skills were identified in a triple threat: dengue, zika and chikungunya. With this identified cut, you can point horizons for better future management and decision making in the area in question. The total number of bibliographic productions by these specialists was 227,801 .

According to the applied methodology (doctors and other researchers, Brazilians and foreign doctors - item 1 of table 1), the total of senior competence in triple threat represents only $0.01 \%$ of the total of doctors specialized in the Lattes platform.

ScriptLattes proved to be effective for retrieving and processing data from specialist CVs included in the Lattes platform. Inconsistencies on the platform, however, may result in some false-positive result, however; in the scope of this research, nothing that would compromise it. Another highlight that can be observed is that the failure to fill out the curricula in a standardized manner by the specialists, can generate data that does not represent reality in each item when rescuing or not. However, by the methodology used in view of the central objective of identifying the senior competences in triple threat, it can be verified that the results obtained were satisfactory.

\author{
PROBLEMS \\ OF MANAGEMENT \\ IN THE $21^{\text {st }}$ CENTURY \\ Vol. 15 , No. 1, 2020 \\ 51
}


Jorge MAGALHÃES, Marcos HIR, Luc QUONIAM, Zulmira HARTZ, Daniele Alves de OLIVEIRA. A management tool to aid in the tropical outbreak of the 21st century: Senior scientists and their knowledge of the triple threat dengue, zika and chikungunya

\author{
PROBLEMS \\ OF MANAGEMENT \\ IN THE $21^{\text {st }}$ CENTURY \\ Vol. 15 , No. 1,2020

\section{Acknowledgements}

The authors thank the Institute of Technology in Drugs Farmanguinhos and the Institute of Technology in Immunobiology Biomanguinhos for the infrastructure and institutional support of FIOCRUZ/Ministry of Health. Likewise, thank the scholarship from the National Council for Scientific and Technological Development (CNPq).

\title{
References
}

Antunes, A. M. S., Mendes, F. M. L., Schumacher, S. O. R., Quoniam, L., \& Magalhães, J. L. (2013). The Contribution of Information Science through Intellectual Property to Innovation in the Brazilian Health Sector: Library and Information Science Book Chapter | IGI Global. In Rethinking the Conceptual Base for New Practical Applications in Information Value and Quality (DOI: 10.4018/978-1-4666-4562-2.ch005; p. 345). IGI Global. http://www.igi-global.com/chapter/ the-contribution-of-information-science-through-intellectual-property-to-innovation-in-thebrazilian-health-sector/84214

Arasu, A., \& Garcia-Molina, H. (2003). Extracting structured data from web pages. In Proceedings of the 2003 ACM SIGMOD International Conference on Management of Data (pp. 337-348). https:// doi.org/10.1145/872757.872799

Bales, M. E., Johnson, S. B., Keeling, J. W., Carley, K. M., Kunkel, F., \& Merrill, J. A. (2011). Evolution of coauthorship in public health services and systems research. American Journal of Preventive Medicine, 41(1), 112-117. https://doi.org/10.1016/j.amepre.2011.03.018

Balmisse, G. (2006a). Guide des Outils du Knowledge Management: Panorama, choix et mise en oeuvre [Knowledge management tools guide: Overview, choice and implementation]. http://www. leslivresblancs.fr/informatique/applications-pro/knowledge-management/livre-blanc/outils-dukm-panorama-choix-et-mise-en-oeuvre-62.html

BRASIL, MCTI. (2016). Estátísticas da Base de Currículos da Plataforma Lattes. http://estatico.cnpq. br/painelLattes/

Brito, A. G. C. de, Quoniam, L., \& Mena-Chalco, J. P. (2016). Exploração da Plataforma Lattes por assunto: Proposta de metodologia [Exploration of the Lattes Platform by subject: Proposed methodology]. Transinformação, 28(1), 77-86. https://doi.org/10.1590/2318-08892016002800006

Costa, L. S., Gadelha, C. A. G., \& Maldonado, J. (2012). A perspectiva territorial da inovação em saúde: A necessidade de um novo enfoque [The territorial perspective of innovation in health: The need for a new approach]. Revista de Saúde Pública, ahead, 0-0. https://doi.org/10.1590/S003489102012005000066

Cowan, R. (2001). Expert systems: Aspects of and limitations to the codifiability of knowledge. Research Policy, 30(9), 1355-1372. https://doi.org/10.1016/S0048-7333(01)00156-1

Dehmer, M., \& Emmert-Streib, F. (2017). Frontiers in Data Science. CRC Press.

Flores, N., \& Silveira, A. C. M. da. (2011). Entre memória e promessa: A identidade de ciência na revista Galileu [Between memory and promise: The identity of science in Galileo journal]. Linguagem em (Dis) curso, 11(2), 263-281. https://doi.org/10.1590/S1518-76322011000200004

Floridi, L. (2010). Information: A very short introduction. Oxford University Press.

Gadelha, C. A. G., Costa, L. S., \& Maldonado, J. (2012). O Complexo Econômico-Industrial da Saúde e a dimensão social e econômica do desenvolvimento [The economic-industrial complex of health and the social and economic dimension of development]. Revista de Saúde Pública, ahead, 0-0. https://doi.org/10.1590/S0034-89102012005000065

Hartz, Z. (2013). From monitoring of performance to the performance of monitoring: New opportunities for evaluation in the management of Health Surveillance. Ciência \& Saúde Coletiva, 18(5), 12211222. https://doi.org/10.1590/S1413-81232013000500005

Hartz, Z. M. de A. (1997). Avaliação em saúde: Dos modelos conceituais à prática na análise da implantação de programas [Health evaluation: From conceptual models to practice in the analysis of the implementation of programs]. Editora FIOCRUZ. http://books.scielo.org/id/3zcft 
Jorge MAGALHÃES, Marcos HIR, Luc QUONIAM, Zulmira HARTZ, Daniele Alves de OLIVEIRA. A management tool to aid in the tropical outbreak of the 21st century: Senior scientists and their knowledge of the triple threat dengue, zika and chikungunya

IDC. (2012). Big Data in 2020 | The Digital Universe in 2020: Big Data, Bigger Digital Shadows, and Biggest Growth in the Far East. IDC analyze the future. https://www.emc.com/leadership/digitaluniverse/2012iview/big-data-2020.htm

Jamil, G. L., Malheiro, A., \& Ribeiro, F. (Orgs.). (2013). Rethinking the Conceptual Base for New Practical Applications in Information Value and Quality: IGI Global. http://www.igi-global.com/ chapter/perception-of-the-information-value-for-public-health/84218

Lastres, HMM, \& Sarita, A. (1999). Informação e Globalização na Era do Conhecimento [Information and globalization in the age of knowledge]. Editora Campus Ltda.

Lawrence, S., \& Giles, C. L. (2000). Accessibility of information on the Web. Intelligence, 11(1), 32-39. https://doi.org/10.1145/333175.333181

Le Moigne, J. L. (1994). La théorie du Système Géneral: Théorie de la modélisation [General System Theory: Modeling Theory]. Presses Universitaires de France.

Lima de Magalhães, J., Mendes, F. M. L., Antunes, A. M. de S., Hartz, Z., Lima de Magalhães, J., Mendes, F. M. L., Antunes, A. M. de S., \& Hartz, Z. (2013). The contribution of information science through scientific and technological knowledge in intellectual property [Chapter]. IGI Global. https://www.igi-global.com/gateway/chapter/208568

Magalhães, J. L. de, Hartz, Z., Menezes, M. S., \& Quoniam, L. (2018). Big Data e a saúde negligenciada em dengue, zika e chicungunha: Uma análise translacional da tríplice ameaça no século 21 [Big Data and neglected health in dengue, zika and chicungunha: A translational analysis of the triple threat in the 21 st century]. Ciência da Informação, 45(3). https://doi.org/10.18225/ci.inf.. v45i3.4061

Magalhães, J., Hartz, Z., Temido, M., \& Antunes, A. (2018). Gestão do conhecimento em tempos de big data: Um olhar dos desafios para os sistemas de saúde [Knowledge management in big data times: A look at the challenges for health systems]. Anais do Instituto de Higiene e Medicina Tropical, 17, 7-16. https://doi.org/10.25761/anaisihmt.256

Magalhaes, J. L., Menezes, M., Hartz, Z., Antunes, A., Magalhaes, J. L., Menezes, M., Hartz, Z., \& Antunes, A. (2018). Information system for knowledge management of the technological platforms in Brazil healthcare [Chapter]. IGI Global. http://Services.Igi-Global.Com/Resolvedoi/ Resolve.Aspx?Doi=10.4018/978-1-5225-6225-2.Ch002. https://www.igi-global.com/gateway/ chapter/208557

Magalhaes, J. L., Martins, M. R. O., \& Hartz, Z. (2015). Big Data em Medicina Tropical: Um panorama do conhecimento científico e tecnológico em malária no mundo e a contribuição de Portugal [BIG DATA in tropical medicine: An overview of the scientific knowledge and technology in malaria in the world and the contribution of Portugal]. Anais Instituto de Higiene e Medicina Tropical, 13, 47-58. https://doi.org/10.25761/anaisihmt.171

Magalhaes, J. L., \& Quoniam, L. (2015). Percepção do valor da informação por meio da inteligência competitiva 2.0 e do Big Data na saúde [Perception of the value of information through competitive intelligence 2.0 and Big Data in health]. In Análise da Informação para Tomada de Decisão: Desafios e soluções (Vol. 1, p. 365). Kira Tarapanoff (Org.).

Magalhaes, J. L., Quoniam, L., Barroso, W., \& Silveira, C. C. F. (2014). Competitive intelligence in health: An analysis of the Big Data for rescuing the neglect of the neglected diseases on last century. World Journal of Nutrition and Health, 2(3), 39-47. https://doi.org/10.12691/jnh-2-3-3

Mena-Chalco, Jesús Pascual, \& Cesar Junior, R. M. (2009). ScriptLattes: An open-source knowledge extraction system from the Lattes platform. Journal of the Brazilian Computer Society, 15(4), 31-39. https://doi.org/10.1007/BF03194511

Mena-Chalco, J. P., Digiampietri, L. A., Lopes, F. M., \& Cesar-Jr., R. M. (2013). Brazilian bibliometric co-authorship networks (http://professor.ufabc.edu.br/ jesus.mena/publications/). in press.

Miles, M. B., \& Huberman, A. M. (1994). Qualitative data analysis: An expanded sourcebook. SAGE.

Minelli, M., Chambers, M., \& Dhiraj, A. (2013). Big Data, Big Analytics. John Wiley \& Sons. https://books. google.com.br/books/about/Big_Data_Big_Analytics.html?hl=pt-BR\&id=Mg3WvT8uHV4C

Ministério da Saúde, M. (2018). SCTIE. Portal da Saúde - Ministério da Saúde - www.saude.gov.br. http://portalsaude.saude.gov.br/index.php/o-ministerio/principal/secretarias/sctie

\section{PROBLEMS \\ OF MANAGEMENT \\ IN THE $21^{\text {st }}$ CENTURY \\ Vol. 15 , No. 1,2020}


Jorge MAGALHÃES, Marcos HIR, Luc QUONIAM, Zulmira HARTZ, Daniele Alves de OLIVEIRA. A management tool to aid in the tropical outbreak of the 21st century: Senior scientists and their knowledge of the triple threat dengue, zika and chikungunya

$\begin{array}{r}\text { PROBLEMS } \\ \text { OF MANAGEMENT } \\ \text { IN THE 21 }{ }^{\text {st }} \text { CENTURY } \\ \text { Vol. 15, No. 1, } 2020 \\ \hline 54\end{array}$

Moon, S., Bermudez, J., \& Hoen, E. (2012). Innovation and access to medicines for neglected populations: Could a treaty address a broken pharmaceutical R\&D system? PLoS Medicine, 9(5), e1001218. https://doi.org/10.1371/journal.pmed.1001218

Morin, E. (1982). Le système: Paradigme ou/et théorie [The system: Paradigm or/and theory]. In: Science avec Conscience. Libraire Arthème Fayard.

Pesqueux, Y. (2005a). Management de la connaissance: Un modèle organisationnel [Knowledge management: An organizational model?]. In Comptabilité et Connaissances, May 2005, France. (pp. CD-Rom). https://halshs.archives-ouvertes.fr/halshs-00004005/document

Pesqueux, Y., \& Ferrary, M. (2011). Management de la connaissance ( $2^{\circ}$ ed). Economica. /Entreprise/ Livre/management-de-la-connaissance-9782717860153

Piaget, J., \& Garcia, R. (1983). Psychogenèse et Histoire des Sciences [Psychogenesis and history of science]. Flammarion.

Pirró, G., Mastroianni, C., \& Talia, D. (2010). A framework for distributed knowledge management: Design and implementation. Future Generation Computer Systems, 26(1), 38-49. https://doi. org/10.1016/j.future.2009.06.004

Quoniam, L. (2011). Competitive intelligence 2.0. ISTE Ltd and John Wiley \& Sons. http://www.iste. co.uk/index.php? $=\mathrm{a} \& A C T I O N=$ View \&id=409

Reinsel, D., Gantz, J., \& Rydning, J. (2018). The digitization of the World from edge to core. https://www. seagate.com/files/www-content/our-story/trends/files/idc-seagate-dataage-whitepaper.pdf

Ross, J. W., Weill, P., \& Robertson, D. (2006). Enterprise architecture as strategy: Creating a foundation for business execution. Harvard Business Review Press.

Selene Xia, B., \& Gong, P. (2014). Review of business intelligence through data analysis. Benchmarking: An International Journal, 21(2), 300-311. https://doi.org/10.1108/BIJ-08-2012-0050

Valverde, A., Magalhães-Fraga, S., Magalhães, J., \& Barroso, W. (2015). Agrobiodiversity products by SWOT analysis as an analysis for strategic innovation. Journal of Technology Management \& Innovation, 10(4), 57-63. https://doi.org/10.4067/S0718-27242015000400006

WHO. (2010). WHO | First WHO report on neglected tropical diseases. WHO. http://www.who.int/ neglected diseases/2010report/en/

WHO. (2018). WHO | Global Forum for Health Research. WHO. http://www.who.int/workforcealliance/ members partners/member list/gfhr/en/

WIPO, W. I. P. O. (2019). WIPO Technology Trends 2019: Artificial Intelligence (p. 158). World Intellectual Property Organization. https://www.wipo.int/publications/en/details.jsp?id=4386

World Bank. (2018). Nearly Half the World Lives on Less than \$5.50 a Day. World Bank. http://www. worldbank.org/en/news/press-release/2018/10/17/nearly-half-the-world-lives-on-less-than-550a-day

Received: April 10, 2020
Accepted: June 05, 2019 
Jorge MAGALHÃES, Marcos HIR, Luc QUONIAM, Zulmira HARTZ, Daniele Alves de OLIVEIRA. A management tool to aid in the tropical outbreak of the 21st century: Senior scientists and their knowledge of the triple threat dengue, zika and chikungunya

Cite as: Magalhaes, J. L., Hir, M. E. L. A., Quoniam, L., Hartz, Z., \& Oliveira, D. A. de. (2020). A management tool to aid in the tropical outbreak of the 21st century: Senior scientists and their knowledge of the triple threat dengue, zika and chikungunya. Problems of Management in the $21^{\text {st }}$ Century, 15(1), 40-55. https://doi.org/10.33225/pmc/20.15.40

\begin{tabular}{|ll|}
\hline $\begin{array}{l}\text { Jorge Magalhães } \\
\text { (Corresponding author) }\end{array}$ & DSc, Researcher in Public Health, Oswaldo Cruz Foundation/FIOCRUZ, \\
& Farmanguinhos, Rua Sizenando Nabuco, 100 - Manguinhos, CEP 21.041- \\
& 250, Brazil. \\
& E-mail: jorge.magalhaes@far.fiocruz.br \\
& Website: https://www.far.fiocruz.br/ \\
\hline Marcos Emiliano Lima Alves & Academic Researcher, Centre for Technological Innovation, Farmanguinhos, \\
Oswaldo Cruz Foundation/FIOCRUZ, Av Brasil, 4365, Zip Code 21040-900, & Brazil. \\
& E-mail: marcos.hir@far.fiocruz.br \\
& Website: https://www.far.fiocruz.br/ \\
\hline Luc Quoniam & DSc, PhD, Professor, Federal University of Mato Grosso do Sul, Brazil; \\
University of Toulon, Avenue de L Université 83957 La Garde, France. \\
E-mail: mail@quoniam.info \\
Website: http://quoniam.info
\end{tabular}

